\title{
The Impact Of The Acceleration Of Information Technology On The Content Of The Accounting Courses: The Case Of GCC
}

\author{
Musa Darayseh, Purdue University \& American University-Sharjah, UAE \\ Elaine Waples, Purdue University Calumet \\ Naser Khaledi, Purdue University Calumet
}

\begin{abstract}
The objective of this study is to examine the status of the accounting curriculum in the Gulf States, from the perspective of accounting graduates of colleges and universities in the Gulf Cooperation Council (GCC). We specifically examine the area of information technology in the accounting curriculum: the preparation provided to the graduate during the university experience as well as the use of information technology on the job. The results support the link between knowledge of information technology and success on the job. Although accounting graduates felt that it was important to study information technology as part of their university education, it appears that the information technology curriculum at GCC colleges and universities has not kept pace with technology advances in the market. Over time there have been improvements, but not enough to keep pace with the rapid changes found in the market. Universities in the Gulf, as well as elsewhere, need to revise their curriculum on a regular basis to provide the knowledge and skills necessary to meet market needs.
\end{abstract}

Keywords: Information Technology, GCC (Gulf Cooperation Council), AIS (Accounting Information System), Accounting Curriculum, Acceleration

\section{INTRODUCTION}

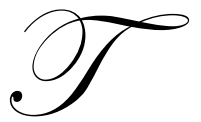

he skills necessary to use information technology effectively are essential to the accounting graduate who is entering the dynamic global business environment of today. Entry-level accountants must recognize the impact of technology on business and be able to use technology effectively to improve business decision-making. [Albrecht and Sack, 2000] While the standards of AACSB International (the Association to Advance Collegiate Schools of Business) do not require specific courses for accreditation, the use of information technology is considered a "general knowledge and skill area" that would be found in most undergraduate degree programs. [AACSB, 2008, p. 72]. More specifically, "information technologies as they influence the structure and processes of organizations and economies, and as they influence the roles and techniques of management," are expected areas of study typically found in general management degree programs. [Ibid] The International Federation of Accountants (IFAC) recognizes the importance of familiarity with information technology, as part of the intellectual and professional skill set of the accounting graduate. [IFAC, 2003] The American Institute of Certified Public Accountants (AICPA) has developed a Core Competency Framework to define the skills necessary for the accounting graduate. [AICPA, 2005] Within the framework, the ability to leverage technology to develop functional and personal competencies as well as a broad business perspective are skills expected of the future professional accountant. 
The objective of this study is to examine the status of the accounting curriculum in the Gulf States, from the perspective of accounting graduates of colleges and universities in the Gulf Cooperation Council (GCC). The countries included are the United Arab Emirates, Qatar, Bahrain, Kuwait, Oman and Saudi Arabia. We specifically examine the area of information technology in the accounting curriculum: the preparation provided to the graduate during the university experience as well as the use of information technology on the job. The results of a survey distributed to GCC accounting graduates will be used to investigate the importance of information technology on the job and the accounting curriculum's relevance to market needs. The rest of the paper is organized as follows. The next section reviews prior literature concerning information technology and accounting information systems, while the following sections describe the research design, data selection, research hypotheses, empirical results, background information on information technology in the accounting curriculum of GCC Universities, and finally, concluding remarks.

\section{LITERATURE REVIEW} Accounting

Much of the research regarding information technology in the accounting curriculum has focused on the

Information Systems (AIS) course, with several studies reporting on topical coverage. Groomer and Murthy [1996] used a survey to study the institutional, course related and instructor-related factors concerning the course. Although there was a wide diversity of topical coverage, most the respondents covered controls, AIS concepts, and the revenue and expense cycles. Respondents mentioned that the AIS course was more difficult to teach than other accounting courses and that they are not satisfied with the AIS textbooks but were satisfied with the computer resources available for teaching the course. Bain, Blankley and Smith [2002] examined the nature and content of the AIS course through a study of textbooks and syllabi. They also surveyed AIS professors and professionals. There seemed to be consensus on three major topics to be emphasized in the course: introduction to systems, transaction processing and internal control. However, there was less agreement regarding the importance of covering spreadsheets, database applications, and general ledger applications. Professionals ranked coverage of ethics, Internet education, and software applications more highly than did faculty.

While earlier research tended to focus on topical coverage in the AIS course, in recent years there has been a shift toward a focus on skill development. The AICPA's core competency framework [AICPA, 2005] specifies skills or competencies that are essential to the professional accountant, as opposed to listing various content areas to be included in the accounting curriculum. This is especially relevant in the rapidly-changing area of information technology.

Knowledge requirements change over time, but skill-based competencies acknowledge the importance of life-long learning for accounting professionals. Daigle, Hayes and Hughes [2007] recognized this paradigm shift from a content-driven to skills-based curriculum. They present a case study of an AIS course based on the competencies included in the AICPA framework. Walters [2007] discussed the close link between information systems, the underlying information technology, and internal controls. Since transaction processing and financial reporting are dependent on information systems, security controls that protect the integrity and confidentiality of an organization's financial data are essential to maintain reliable internal controls. Since information technology professionals may not have the knowledge of accounting and internal control processes, accounting professionals must take up the slack. Walters argues for a separate information systems security course within the accounting curriculum and offers a framework for course design.

\section{RESEARCH DESIGN}

\section{Sample Selection and Data}

A survey was used to gather data concerning the importance of information technology on the job and the accounting curriculum's relevance to market needs. The sample used in this study was drawn from companies within the Gulf Cooperation Council countries. Eleven hundred questionnaires were sent to accountants in the 
various companies, with instructions that respondents be accounting graduates of the GCC colleges and universities. There were 431 valid responses received, a response rate of $39.18 \%$. Table 1 shows the years of graduation for respondents, and Table 2 presents the number of respondents based on company classification.

Table 1: Respondent Based on Year of Graduation

\begin{tabular}{|c|c|c|}
\hline Year of Graduation & Number of Respondents & Percentage \\
\hline 1990 to 1995 & 74 & $17.18 \%$ \\
\hline 1996 to 2000 & 175 & $40.60 \%$ \\
\hline 2001 to 2006 & 182 & $42.22 \%$ \\
\hline Total & 431 & $100 \%$ \\
\hline
\end{tabular}

Table 2: Respondent Based on Company Classification

\begin{tabular}{|c|c|c|}
\hline Type of Company & Number of Respondents & Percentage \\
\hline Industrial companies & 38 & $8.80 \%$ \\
\hline Commerce Companies & 118 & $27.40 \%$ \\
\hline Financial Companies & 168 & $38.98 \%$ \\
\hline Services Companies & 107 & $24.82 \%$ \\
\hline Total & 431 & $100 \%$ \\
\hline
\end{tabular}

\section{Research Hypotheses}

The hypotheses tested in this study are as follows:

H1: An adequate knowledge in the information technology area affects the work success of the GCC graduates.

H2: The acceleration improvements of the information technology in the market have an effect on the improvement of the accounting curriculum at the GCC colleges and universities.

H3: The information technology curriculum at GCC colleges and universities meets market needs.

H4: Over time, improvements in technology have led to improvements of the accounting curriculum to meet market needs.

\section{Methodology and Empirical Results}

This study used descriptive statistics analysis, T-tests, and ANOVA to test the hypotheses presented above. Cronbach's alpha $(\alpha)$ was used to demonstrate the reliability of the instrument. The value of $\alpha$ was $83.47 \%$ which means that the reliability is acceptable. (Note that a reliability coefficient of $70 \%$ or higher is considered acceptable in most social science research studies but not to exceed 90\%). [SPSS, UCLA] 
Table 3 (H1): An adequate knowledge in the information technology area affects the work success of the GCC graduates

\begin{tabular}{|c|c|c|c|c|}
\hline & Mean & Median & S.D. & P value \\
\hline 1. In my work I need a computer & 4.7193 & 5 & 0.74 & 0.000 \\
\hline 2. My knowledge in computers helps me to get a better job & 4.6032 & 5 & 0.86 & 0.005 \\
\hline $\begin{array}{l}\text { 3. My knowledge in computers gives me the advantage over } \\
\text { others enabling me to get a job faster than others }\end{array}$ & 4.1508 & 5 & 0.63 & 0.007 \\
\hline 4. My knowledge in computers helps me to be promoted faster & 4.0255 & 4 & 0.13 & 0.325 \\
\hline 5. My knowledge in computers makes my work life easier & 4.5754 & 5 & 0.35 & 0.000 \\
\hline $\begin{array}{l}\text { 6. My knowledge in computers makes my communication with } \\
\text { others easier and faster }\end{array}$ & 4.4733 & 5 & 0.87 & 0.193 \\
\hline $\begin{array}{l}\text { 7. My knowledge in computers helps me to do my current job } \\
\text { better }\end{array}$ & 4.4478 & 5 & 0.91 & 0.018 \\
\hline 8. I need the computer outside my work environment & 4.0232 & 5 & 0.99 & 1 \\
\hline $\begin{array}{l}\text { 9. I am always in need for computer training to be up to date in } \\
\text { doing my job }\end{array}$ & 4.2207 & 4 & 0.45 & 0.013 \\
\hline
\end{tabular}

Table 3 presents the results that test the first hypothesis, state above. The overall mean for the group of questions related to the first hypothesis is 4.361 , the median is 4.87 , and the standard deviation is 0.58 . This result is an indicator that the respondents believe that adequate computer knowledge for accounting graduates is very important for their future success. These results were supported by most of the respondents because the median is 4.87. To test the significance level of the hypothesis, the T-statistic was employed at a level of 5\%. The p value was 0.017 which means that there was $98.3 \%$ acceptance from the respondents and this is higher than the significance rate set for this study which is $95 \%$. This result provides strong evidence that the above hypothesis is supported. Technology skills are important to success in the marketplace. This result also suggests that the curriculum for the accounting departments at the colleges and universities of the GCC should be revisited and updated to meet market needs.

Table 4 provides information that tests the third hypothesis, stated above. The overall mean for the group of questions related to the second hypothesis is 4.1806 , the median is 4.8333 , and the standard deviation is 0.49 . This result is an indicator that the respondents believe that the improvements in information technology have an effect on the improvements of the plan of study and on the accounting courses that should be offered by the program. This result also is an indicator that the respondents believe that it is important to be exposed to information technology and to develop computer skills during their school years, reinforcing the importance of keeping the information technology segment of the accounting curriculum up-to-date to meet market needs. To test the significance level of the hypothesis, the T-statistic was employed at a level of 5\%. The p value was 0.002 which means that there was 99.8\% acceptance from the respondents and this is higher than the significance rate set for this study which is $95 \%$. This result provides strong evidence that the above hypothesis is supported. Accounting graduates feel that information technology is an important part of a university education.

Table 4 (H2): The acceleration improvements of the information technology in the market have an effect on the improvement of the accounting curriculum at the GCC colleges and universities

\begin{tabular}{|c|c|c|c|c|}
\hline & Mean & Median & S.D & P value \\
\hline 1. It is important for my job that I know how to use data bases & 4.0046 & 5 & 0.76 & 0.563 \\
\hline 2. It is important to know how to use spreadsheets in my job & 4.0209 & 4 & 0.89 & 0.391 \\
\hline $\begin{array}{l}\text { 3. It is important to study how to use computer packages and } \\
\text { programs during school years }\end{array}$ & 4.1392 & 5 & 0.45 & 0.008 \\
\hline 4. It is important to study how to use computers in auditing & 3.9118 & 5 & 0.65 & 0.036 \\
\hline $\begin{array}{l}\text { 5. It is important to study internet communication facilities } \\
\text { and their uses }\end{array}$ & 4.6381 & 5 & 0.47 & 0.178 \\
\hline $\begin{array}{l}\text { 6. It is very important to understand the computer system that } \\
\text { I use at my work }\end{array}$ & 4.3689 & 5 & 0.66 & 0.002 \\
\hline
\end{tabular}


Table 5 (H3): The information technology curriculum at GCC colleges and universities meets market needs.

\begin{tabular}{|c|c|c|c|c|}
\hline & Mean & Median & S.D. & P value \\
\hline $\begin{array}{l}\text { 1. The AIS and other courses I took during my school years } \\
\text { were enough to help me do other things outside my job environment }\end{array}$ & 2.7935 & 4 & 1.23 & 0.003 \\
\hline $\begin{array}{l}\text { 2. The courses that I took during my school years discussed the } \\
\text { needs of companies and institutions for information (data bases) } \\
\text { and planning. }\end{array}$ & 2.4965 & 2 & 1.09 & 0.356 \\
\hline $\begin{array}{l}\text { 3. The courses that I took during my school years discussed } \\
\text { the problems that face companies and institutions regarding } \\
\text { control of information. }\end{array}$ & 3.0046 & 2 & 0.97 & 0.063 \\
\hline $\begin{array}{l}\text { 4. The courses that I took during my school years discussed the } \\
\text { problems that faces companies and institutions regarding } \\
\text { using and distribution of data bases }\end{array}$ & 2.7401 & 2 & 0.88 & 0.417 \\
\hline $\begin{array}{l}\text { 5. There is a strong relationship between the courses I took at } \\
\text { school and uses of the data bases at my job }\end{array}$ & 2.6682 & 2 & 0.95 & 0.004 \\
\hline
\end{tabular}

Table 5 provides information that tests the second hypothesis, stated above. The overall mean for the group of questions related to the third hypothesis is 2.740 , the median is 2.400 , and the standard deviation is 0.38 . The respondents indicate that there is a gap between the technology courses they took at their universities and the market needs regarding technology. These results were supported by the rejection of the respondents for the questions that were related to this hypothesis. To test the significance level of the hypothesis, the T-statistic was employed at a level of $5 \%$. The p value was 0.0001 which means that there $99.9 \%$ acceptance from the respondents and this is higher than the significance rate set for this study which is $95 \%$. This result provides strong evidence that the above hypothesis is rejected. The university curriculum does not appear to be keeping up with the rapidly-changing information technology improvements in the marketplace.

To assess the improvements of technology and their effects on accounting curricula over time, we examined the difference between the three group's respondents' opinion based on date of graduation (1990-1995, 1996-2000, and 2000-2006). Table 6 presents the means of the opinion of the three groups. It is clear from the means that there are improvements in the information technology curriculum over time. The mean for group one (1990-1995) was 1.997, for group two (1996-2000), it was 2.771, and for group 3 (2001-2006), it was 3.450.

Table 6: (H4): Over time, improvements in technology have led to improvements of the accounting curricula to meet market needs.

\begin{tabular}{|c|c|c|c|}
\hline & $\begin{array}{l}\text { Graduated } \\
1990-1995\end{array}$ & $\begin{array}{l}\text { Graduated } \\
1996-2000\end{array}$ & $\begin{array}{l}\text { Graduated } \\
\text { 2001-2006 }\end{array}$ \\
\hline & Mean & Mean & Mean \\
\hline $\begin{array}{l}\text { The AIS and other courses I took during my school years } \\
\text { were enough to help me do other things outside my job } \\
\text { environment. }\end{array}$ & 2.208 & 2.823 & 3.349 \\
\hline $\begin{array}{l}\text { 2. The courses that I took during my school years discussed the needs of } \\
\text { companies and institutions for information (data bases) and planning. }\end{array}$ & 1.681 & 2.534 & 3.274 \\
\hline $\begin{array}{l}\text { 3. The courses that I took during my school years discussed } \\
\text { the problems that face companies and institutions } \\
\text { regarding control of information. }\end{array}$ & 2.246 & 2.0987 & 3.781 \\
\hline $\begin{array}{l}\text { 4. The courses that I took during my school years discussed the } \\
\text { problems that face companies and institutions regarding } \\
\text { using and distribution of data bases. }\end{array}$ & 1.864 & 2.840 & 3.516 \\
\hline $\begin{array}{l}\text { 5. There is a strong relationship between the course I took } \\
\text { at school and uses of the data bases at my job. }\end{array}$ & 1.986 & 2.669 & 3.348 \\
\hline
\end{tabular}


The analysis of variance (TWO-WAY ANOVA) is used to detect if there are any differences among the mean of these groups. Table 7 shows that the $\mathrm{F}$ value using a significance level of 0.05 with degrees of freedom of 4 and 2 is 6.94 . The calculated value of $F$ test statistics for 4 and 2 degrees of freedom is 8.43 . This indicates that the means of the three different groups are significantly different from each other at the 0.05 level of significance. Although the accounting curriculum is clearly deficient as evidenced by the survey results, it does appear to be improving over time, as technology advances appear in the market.

Table 7 (ANOVA TWO FACTORS)

\begin{tabular}{|c|c|c|c|c|c|c|}
\hline Source of Variation & $\boldsymbol{S S}$ & $\boldsymbol{D f}$ & $\boldsymbol{M S}$ & $\boldsymbol{F}$ & $\boldsymbol{P}$-value & $\boldsymbol{F}$ crit \\
\hline Rows & 0.412493 & 4 & 0.103123 & 8.433587 & 0.005716 & 3.83785 \\
\hline Columns & 5.311049 & 2 & 2.655525 & 217.1732 & $1.07 \mathrm{E}-07$ & 4.45897 \\
\hline Error & 0.097821 & 8 & 0.012228 & & & \\
\hline Total & & & & & & \\
\hline
\end{tabular}

\section{BACKGROUND INFORMATION}

To provide a frame of reference for the results of the survey reported above, the authors collected data regarding information technology in the accounting curriculum at GCC universities. The facts were collected from various sources, including faculty, web pages, and syllabi. While the information is anecdotal in nature, it may help to provide a context for our results.

Courses that have to be included in the curriculum for a bachelor degree in accounting are determined by each university but degrees and courses must be approved by the Ministry of Higher Education of each country. We found that the plan of study for an accounting degree typically included the following:

1. The plan included between 123 and 132 credit hours

2. Credit hours in information technology are between 9 and 12 hours, about $9 \%$ of the total credit hours

3. In many cases, information technology was not used in important courses such as statistics, financial analysis, and other quantitative courses.

4. Some courses are taught in isolation, without firm connections to the rest of the curriculum.

5. There seems to be a lack of attention to coverage of areas such as data availability, collection, storage, security, and processing.

6. Student populations are large, and in some cases, there is a shortage of computer resources and qualified computer advisors. Thus, some courses tend to be taught theoretically.

7. The AIS course is included in the plan of study at all universities, but in some cases it is not offered on a regular basis.

\section{CONCLUDING REMARKS}

In this study, we examined the status of the accounting curriculum in the Gulf States, from the perspective of accounting graduates of colleges and universities in the Gulf Cooperation Council (GCC). We specifically looked at the area of information technology in the accounting curriculum and the use of information technology on the job. The results support the link between knowledge of information technology and success on the job. Although accounting graduates felt that it was important to study information technology as part of their university education, it appears that the information technology curriculum at GCC colleges and universities has not kept pace with technology advances in the market. Over time there have been improvements, but not enough to keep pace with the rapid changes found in the market. Information technology is an integral part of the accounting curriculum and it is an essential element in the skill set of the accounting professional. Universities in the Gulf, as well as elsewhere, need to revise their curriculum on a regular basis to provide the knowledge and skills necessary to meet market needs. 


\section{AUTHOR INFORMATION}

Musa Darayseh is a professor of accounting at the American University of Sharjah and Purdue University Calumet. His current research interests include market studies, bankruptcy, and accounting education. He published at the Journal of College Teaching and Learning, Journal of Applied Business Research, and Journal of Business and Economic Research.

Elaine Waples is an associate professor of accounting at Purdue University Calumet. Her Current Research interest includes tax education, accounting education and accounting ethics. She published at the He published at the Journal of College Teaching and Learning and Journal of Business and Economic Research.

Naser Khaledi is an assistant professor of accounting at Purdue University calumet. His current research interest includes corporate governance, auditing and market studies.

\section{REFERENCES}

1. AACSB International - The Association to Advance Collegiate Schools of Business, (January 2008). Eligibility Procedures and Accreditation Standards for Business Accreditation, Tampa, Florida, USA, available at http://www.aacsb.edu

2. Albrecht, W. Steve and Robert J. Sack, (2000). Accounting Education: Charting the Course through a Perilous Future, American Accounting Association, Sarasota, Florida, USA.

3. American Institute of Certified Public Accountants (AICPA), (2005). Core Competency Framework, New York New York, USA, available at http://ceae.aicpa.org/Resources

4. Bain, C.E., Blackely, A.I. and Smith, L.M., 2002. An Examination of Topical Coverage for the First Accounting Information Systems Course. Journal of Information Systems. 10(2): 103-127.

5. Daigle, Ronald J., David C Hayes, and K. E. Hughes II, 2007. Assessing Student Learning Outcomes in the Introductory Accounting Information Systems Course Using the AICPA's Core Competency Framework, Journal of Information Systems, 21(1): 149- 169.

6. Groomer, S.M. and Murthy U.S. 1990. An Empirical Analysis of the Accounting Information Systems Course. Journal of Information Systems. 16(2): 143-164.

7. International Federation of Accountants, International Education Standards for Professional Accountants, IFAC.org, October 2003.

8. $\quad$ SPSS. UCLA: Academic Technology Services, Statistical Consulting Group. http://www.ats.ucla.edu/stat/spss/faq/alpha.html (accessed January 29, 2008).

9. Walters, L. Melissa, (2007). A Draft of an Information Systems Security and Control Course, Journal of Information Systems, 21:1: 234-148. 
NOTES 